\title{
Diet Preferences of Small Fishes at Setiu Lagoon, Malaysia
}

\author{
Zaleha Kassim ${ }^{1 *}$, Muhammad Solleh Majid ${ }^{2}$, Nur Yahdiyani Mat Alwi ${ }^{2}$ and Hazwani Hanim Hasnan ${ }^{1}$ \\ ${ }^{1}$ Department of Marine Science and Technology, Kulliyyah of Science, International Islamic University Malaysia \\ (IIUM), Jln Sultan Ahmad Shah, 25200, Kuantan Pahang \\ ${ }^{2}$ Fisheries and Aquaculture Science Department, Faculty of Agrotechnology and Food Science, Universiti Malaysia \\ Terengganu, Kuala Terengganu, Terengganu \\ E-mail: drzack@iium.edu.my
}

\begin{abstract}
This study aimed to investigate diet preferences of small fishes in a shallow coastal lagoon through analysis of their stomach contents. The 24 hours samplings was done during high tide at selected stations; mangrove areas and seagrass areas, both located at coastal lagoon of Setiu, Terengganu (N $5^{\circ} 41.75^{\prime} \mathrm{E} 102^{\circ} 42^{\prime}$ to $\left.\mathrm{N} 5^{\circ} 42.5^{\prime} \mathrm{E} 102^{\circ} 41^{\prime}\right)$. The small fishes were caught using seine nets $\left(0.5 \mathrm{~cm}^{2}\right)$, while the zooplanktons were collected using Kitahara zooplankton net (110 microns) then were preserved. All items found in the stomach were compared with the composition of the zooplanktons obtained from the water samples. During the sampling time, 10 species of small fishes were caught. There were higher number of fishes and zooplanktons caught from the seagrass areas than the mangrove areas. Nonetheless, diversity of zooplankton was higher in the mangroves. Overall, the number of harpacticoid was higher than all other food items found in the stomach of fishes caught from both areas despite the high number of calanoid copepods found in the lagoon.
\end{abstract}

Keywords: Copepods, diet, Setiu Lagoon, small fishes

\section{Introduction}

Zooplankton is an important community in aquatic ecosystem for energy transfer from primary producer to fishes [1]. Factors such as species and ecosystem type could easily influence the feeding of small fishes [2 and 3]. The ecosystem condition could increase the foraging efficiency and lessen predation risk in the fishes $[4,5$ and 6$]$. The strong relationship between juvenile fishes with the planktonic calanoid copepods in Chikugo estuary in Japan was reported [6]. Despite that, some juvenile fishes prefer non-calanoid copepods and other small zooplanktons as their diet [7].

Juveniles of Lutjanus jocu, for example, were reported to depend on seasonal variability of preys [8]. Nonetheless, juveniles of salmons were reported to have their preference diet constant despite the fluctuation in the abundance of preys [9]. The seasonal correlation between the density of fishes and their main prey in two estuary habitats, was reported [10] that indicating the influence of prey abundance to the predators.

Setiu lagoon in Terengganu is a shallow lagoon, receiving seawater from South China Sea. The maximum depth during the period of this study was only 3 meters. Even though the lagoon has been reported to be overexploited by aquaculture activities and pollution issues [11], the physical water quality remained in Class I according to the Department of Environment Malaysia [12]. Small fish population in such habitat could be very sensitive towards water condition in the area [13]. Small fishes are more opportunistic in nature that they are able to adapt and survive in stressful conditions of shallow lagoons [14]. Diet preference of the small fishes from Setiu lagoon could be related to the zooplankton community that could be a combination of benthic and truly planktonic group due to the shallow water condition. Fringing mangroves and patches of seagrass in the lagoon could somehow support the function of the lagoon as feeding ground for small fishes [3 and 4]. This study focused on the stomach contents of small fishes found in Setiu lagoon. It will improve our understanding on their preferences towards zooplanktons found in the ecosystem. This information could be used to develop a sustainable management plan for shallow coastal habitat such as Setiu Lagoon in Terengganu.

\section{Materials and Methods}




\subsection{Field Sampling}

Field sampling of this study was carried out at Setiu Lagoon, which was located parallel to the South China Sea. Two stations were chosen; the seagrass area (N 5 $41.75^{\prime} \mathrm{E} 102^{\circ} 42^{\prime}$ ) and the mangrove forest $\left(\mathrm{N} 5^{\circ} 42.5^{\prime} \mathrm{E} 102^{\circ} 41^{\prime}\right)$ both shown in Figure 1. Sea water enters the lagoon during the tidal exchange within 24 hours. Three sampling times were chosen within this period; 0700-0900 hours and 2100-2200 hours for the first day and in the morning of the second day at 0700-0900 hours to deploy the seine nets $\left(0.5 \mathrm{~cm}^{2}\right)$ at the selected stations. Fish samples were preserved in $80 \%$ ethanol to prevent further digestion process in the stomach. A Kitahara zooplankton net (120 microns) was used to collect zooplanktons in the same sampling site. The zooplanktons collected were fixed with $5 \%$ buffered formalin. The water parameters including salinity, dissolved oxygen and temperature were measured using the YSI Multi-probe instrument (model 09L100682).

\subsection{Laboratory Analyses}

In the laboratory, fish samples were measured for the total and standard of lengths and weights. Species identification of the fishes was based on the lowest possible taxonomic level. Then, the scissor was introduced in the anus of the fish. The abdominal muscle was carefully cut to avoid damage to the alimentary system. Incision upwards was made to the lateral line toward the head of the fish until its chest. From the chest, an incision was made along the chest backwards to the anus. The stomach was cut out, weighted, and placed on a petri dish for further observation. All identified food items were quantified in terms of percentage of volumetric composition and frequency of occurrence. Zooplankton samples were quantified from the subsampling strategy approach [15] and observed using a stereo microscope (Leica model).

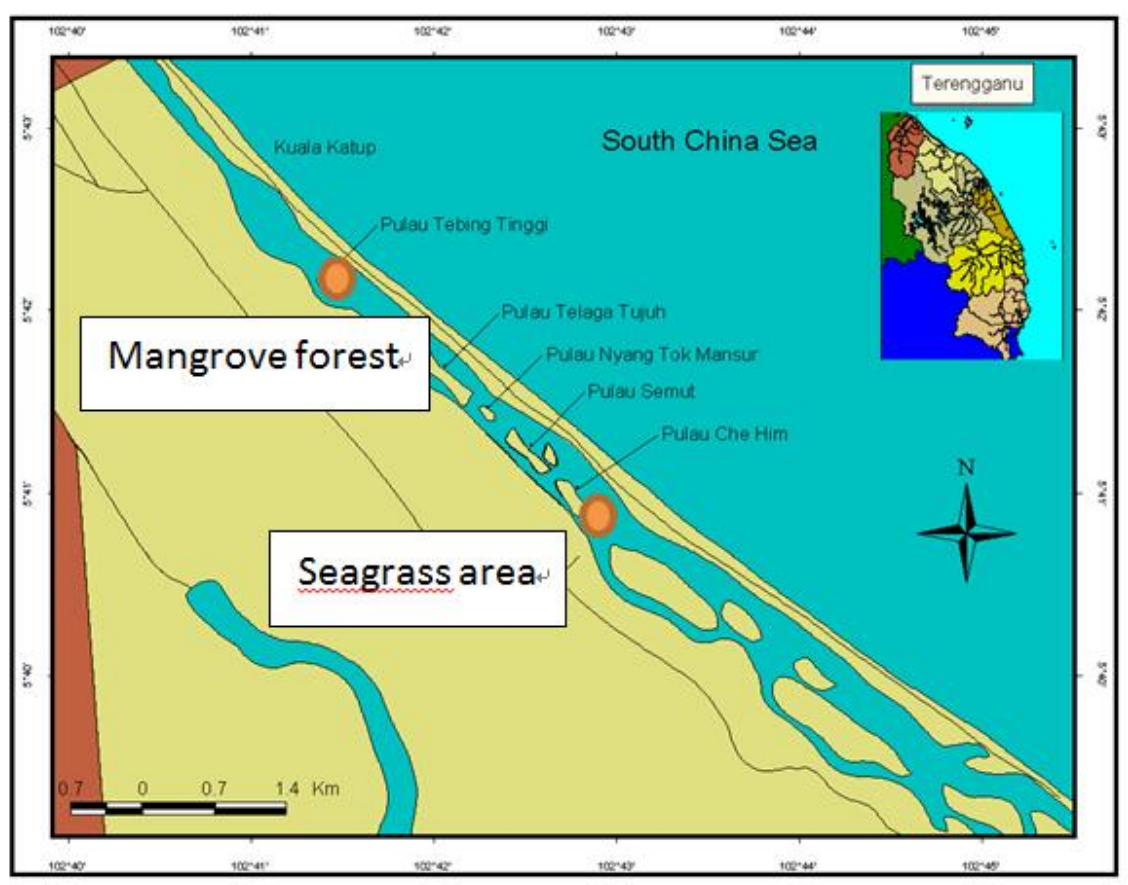

Figure 1. Sampling stations at Setiu Lagoon, Terengganu, Malaysia. Small map shows the State of Terengganu.

\section{Results}

\subsection{Environmental Parameters}

The high tide level during the sampling was $1.7 \mathrm{~m}, 2.1 \mathrm{~m}$, and $1.7 \mathrm{~m}$ in the morning, night and the following morning respectively. There was a fluctuation of salinity, temperature, dissolved oxygen and 
$\mathrm{pH}$ from both sampling sites (Table 1 and Table 2). Nonetheless, at night when higher tide brought in more seawater, the salinity increased to about the same as that of the seagrass area. In addition to that, the high tide during night time had also reduced the warm condition experienced by the lagoon during daytime.

Table 1. Salinity (ppt), temperature $\left({ }^{\circ} \mathrm{C}\right), \mathrm{pH}$ and dissolved oxygen, DO $(\mathrm{mg} / \mathrm{L})$ recorded in-situ in the seagrass in 24 hours at Setiu Lagoon

\begin{tabular}{lllll}
\hline Time (hour) & Salinity (ppt) & Temperature $\left({ }^{\circ} \mathrm{C}\right)$ & Dissolved oxygen $(\mathrm{DO})(\mathrm{mg} / \mathrm{L})$ & $\mathrm{pH}$ \\
\hline 0735 & $26.21 \pm 0.10$ & $30.84 \pm 0.04$ & $5.60 \pm 2.10$ & $8.04 \pm 0.02$ \\
2129 & $31.05 \pm 0.12$ & $26.34 \pm 1.01$ & $5.25 \pm 1.80$ & $8.20 \pm 0.10$ \\
0753 & $26.05 \pm 1.01$ & $30.38 \pm 0.56$ & $5.22 \pm 2.00$ & $8.46 \pm 0.12$ \\
\hline
\end{tabular}

Table 2. Salinity (ppt), temperature $\left({ }^{\circ} \mathrm{C}\right), \mathrm{pH}$ and dissolved oxygen, DO $(\mathrm{mg} / \mathrm{L})$ recorded in-situ in the mangroves in 24 hours at Setiu Lagoon

\begin{tabular}{lllll}
\hline Time (hour) & Salinity (ppt) & Temperature $\left({ }^{\circ} \mathrm{C}\right)$ & Dissolved oxygen $(\mathrm{DO})(\mathrm{mg} / \mathrm{L})$ & $\mathrm{pH}$ \\
\hline 0900 & $20.71 \pm 1.00$ & $30.78 \pm 0.25$ & $3.05 \pm 0.20$ & $7.65 \pm 0.01$ \\
2129 & $31.00 \pm 1.01$ & $24.24 \pm 0.11$ & $4.33 \pm 0.01$ & $8.03 \pm 0.21$ \\
0930 & $20.60 \pm 1.00$ & $30.54 \pm 0.50$ & $3.34 \pm 1.50$ & $7.68 \pm 0.25$ \\
\hline
\end{tabular}

\subsection{Zooplankton Composition and Density}

During the 24 hours sampling period, zooplankton community showed different composition between the sampling sites (Figure 2 and Figure 3). Zooplankton consisted of at least six identified groups; calanoida, cyclopoida, harpacticoida, polychaeta, molluska and chordata. Ten taxa of zooplankton were found in the mangroves and only seven taxa in the seagrass. Nonetheless, the seagrass had supported denser community than the mangroves. The density of the seagrass reached more than $4000 \mathrm{ind} / \mathrm{L}$, while the number became lesser in the mangroves. Calanoid copepods consistently dominated both sampling sites during all sampling times (167 to 650 ind/L in mangroves and 753 to 4154 ind/L in seagrass). On the other hand, harpacticoid copepods occurred in a small number (50 to 183 ind/L in mangroves and 54 to 274 ind/L in seagrass).

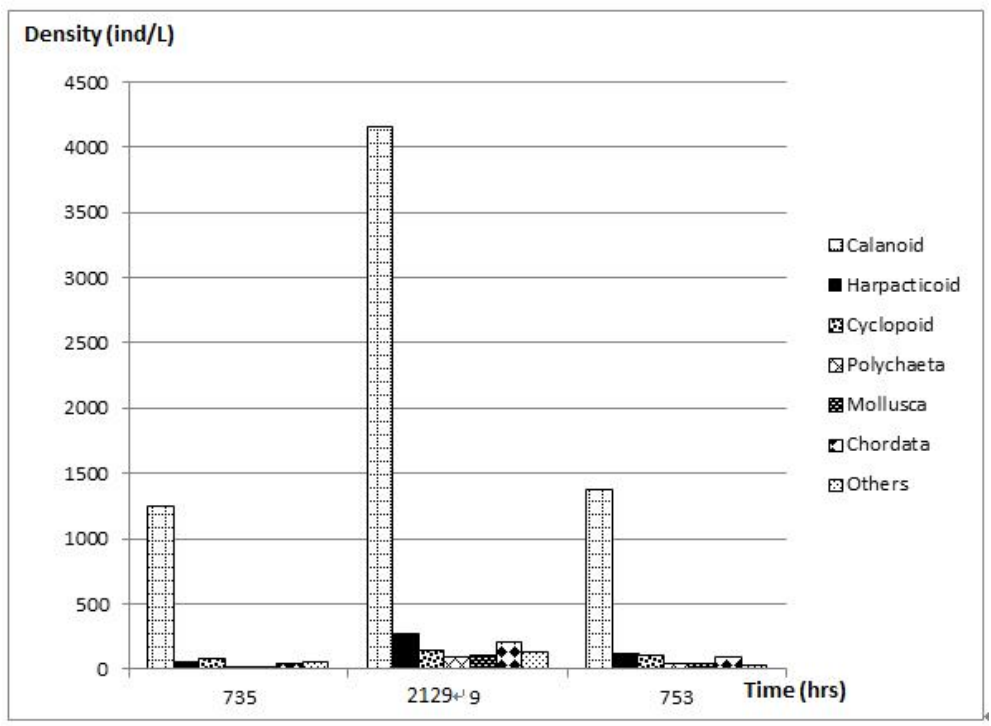

Figure 2. Zooplankton density (ind/L) and composition in the seagrass area at Setiu Lagoon in 24 hours 


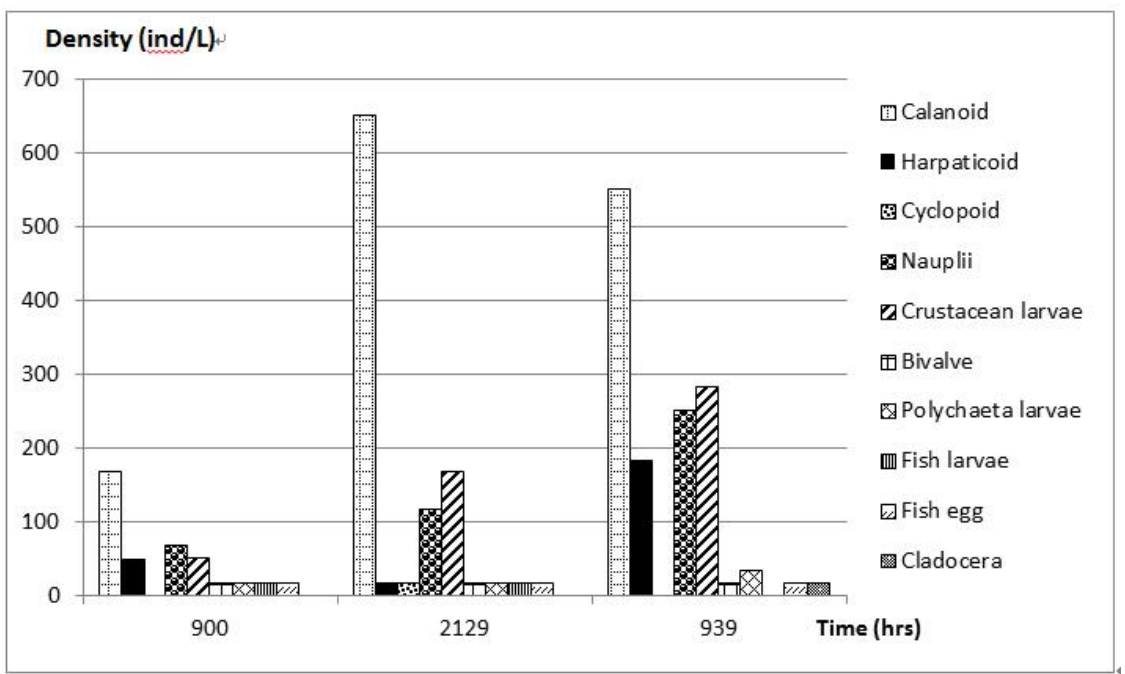

Figure 3. Zooplankton density (ind/L) and composition in the mangroves at Setiu Lagoon in 24 hours

\subsection{Fishes Caught in Setiu Lagoon}

Table 3 and Table 4 show the species of fishes caught during the sampling period. Higher numbers of fishes were caught from the seagrass bed (34 individuals) than the mangroves (18 individuals). Fishes caught from the seagrass area were more diverse than those from the mangroves. The catch was higher during the night than in the morning particularly in the seagrasses.

Gerreidae Bleeker, 1859 represented by G. abbreviatus, G. filamentosus and G. oyena found in both mangroves and seagrass area throughout the sampling. They could be the most common group occurred in the lagoon. Leiognathus brevirostris, S. vincenti, T. quadrilineatus, L. subviridis, S. canaliculatus and A. interupta were found in small number and occurred either in the mangroves or seagrasses.

Table 3. Number of fishes caught in the seagrass in 24 hours at Setiu Lagoon

\begin{tabular}{lllll}
\hline \multirow{2}{*}{ Fish Species } & \multicolumn{4}{l}{ TIME (hrs) } \\
\cline { 2 - 6 } & 0735 & 2129 & 0753 \\
\hline Sillago vincenti Mckay, 1980 & 5 & 0 & 0 & \\
Gerres abbreviatus Bleeker, 1850 & 4 & 5 & 0 & \\
Gerres oyena (Forsskål, 1775) & 3 & 10 & 1 & \\
Therapon quadrilineatus (Bloch, 1790) & 1 & 0 & 0 & \\
Liza subviridis (Valenciennes, 1836) & 2 & 0 & 0 & \\
Siganus canaliculatus (Park, 1797) & 0 & 2 & 0 & \\
Ambasis interupta, Bleeker, 1853 & 0 & 0 & 1 & \\
TOTAL & 15 & 17 & 2 & 34 \\
\hline
\end{tabular}

Table 4. Number of fishes caught in the mangroves in 24 hours at Setiu Lagoon

\begin{tabular}{llllll}
\hline \multirow{2}{*}{ Fish Species } & \multicolumn{5}{l}{ TIME (hrs) } \\
\cline { 2 - 6 } & 0900 & 2129 & 0753 \\
\hline Gerres abbreviatus Bleeker, 1850 & 0 & 2 & 3 & \\
Gerres filamentosus Cuvier, 1829 & 0 & 0 & 2 & \\
Gerres oyena (Forsskål, 1775) & 0 & 0 & 1 & \\
Leiognathus brevirostris (Valenciennes, 1835) & 0 & 3 & 1 & \\
Leiognathus equulus (Forsskål, 1775) & 2 & 3 & 1 & \\
TOTAL & 2 & 8 & 8 & 18 \\
\hline
\end{tabular}




\subsection{Fish Stomach Content}

Small fishes caught from the lagoon showed low number of food item (less than 10 items) in their stomach. Most fishes consumed harpacticoid copepods, except for S.vincenti. Unexpectedly, A. interupta and $S$. canaliculatus were found in empty stomach condition (Table 5).

Table 5. Three most common diet items (\%) found in fishes caught in 24 hours sampling at Setiu Lagoon

\begin{tabular}{ll}
\hline Fish Species & Most common diet (\%) \\
\hline Ambasis interupta & Empty stomach \\
Gerres abbreviates & Harpacticoids: 14.3-92.5\%, \\
& Polychaeta larvae: $25-28.6 \%$ \\
& Crustacean larvae: $14.3-25.0 \%$ \\
Gerres oyena & Harpacticoids: $12.5-66.7 \%$ \\
& Calanoids: $12.5-50.0 \%$ \\
& Molluska: $50 \%$ \\
Gerres filamentosus & Harpacticoids: $50.0 \%$ \\
& Crustacean larvae: $25 \%$ \\
& Polychaeta: $25 \%$ \\
Leiognatus equulus & Harpacticoids: $60.0-75.0 \%$ \\
& Calanoids: $30.0-75.0 \%$ \\
& Fish larvae: $25.0 \%$ \\
Leiognatus brevirostris & Harpacticoids: $44.0-50.0 \%$ \\
& Calanoids: $44.0-50.0 \%$, \\
& Siphonostomatoida: $10 \%$ \\
Liza subviridis & Harpacticoids: $20.0 \%$ \\
& Calanoids: $20.0 \%$ \\
& Molluska: $20 \%$ \\
Therapon quadrilineatus & Harpacticoids: $43.5 \%$ \\
& Crustacean larvae: $30.4 \%$ \\
& Calanoids: $17.4 \%$ \\
& Empty stomach \\
& Polychaeta: $50.0 \%$ \\
& Crustacean larvae: $50.0 \%$ \\
\hline &
\end{tabular}

Table 6. Frequency of occurrence and percentage of food items found in juvenile fishes in the seagrass at Setiu Lagoon

\begin{tabular}{|c|c|c|c|c|c|c|c|}
\hline \multirow{4}{*}{ Food item } & \multirow[b]{4}{*}{ Fish observed: } & \multicolumn{6}{|c|}{ TIME (hrs) } \\
\hline & & \multicolumn{2}{|l|}{0735} & \multicolumn{2}{|c|}{2129} & \multicolumn{2}{|l|}{0753} \\
\hline & & 15 & & 17 & & 2 & \\
\hline & & Occurrence & $\%$ & Occurrence & $\%$ & Occurrence & $\%$ \\
\hline Harpacticoid & & 12 & 80 & 3 & 17.7 & 0 & - \\
\hline Calanoid & & 5 & 33.3 & 3 & 17.7 & 1 & 50.0 \\
\hline Cyclopoid & & 2 & 13.3 & 1 & 2.8 & 0 & 0 \\
\hline Crustacean larvae & & 0 & 0 & 2 & 25.0 & 6 & 75.0 \\
\hline Polychaeta & & 4 & 26.7 & 5 & 29.4 & 0 & 0 \\
\hline Mollusca & & 0 & 0 & 1 & 5.9 & 1 & 50.0 \\
\hline Fish larvae & & 0 & 0 & 3 & 17.7 & 0 & 0 \\
\hline Nauplii & & 1 & 6.7 & 1 & 5.9 & 0 & 0 \\
\hline Nematoda & & 1 & 6.7 & 0 & 0 & 0 & 0 \\
\hline
\end{tabular}

Higher numbers of food items were found in the stomach content of fishes caught from the seagrass area than the mangrove area (Table 6 and Table 7). Harpacticoid copepods were the most food item 
found. Samples caught from the seagrass area reported that harpacticoids had contributed to the fishes' diets ( $17 \%$ to $80 \%$ ), followed by the contribution of crustacean larvae (25\% to $75 \%$ ). On the other hand, calanoid copepods contributed only $17 \%$ to $50 \%$ from the diet. Meanwhile, harpacticoids contributed $88 \%$ to $100 \%$ to the fishes' diets in the mangrove area. This was followed by calanoids (50\% to $88 \%$ ) and crustacean larvae (25\% to $75 \%)$.

Table 7. Frequency of occurrence and percentage of food items found in juvenile fishes in the mangroves at Setiu Lagoon

\begin{tabular}{|c|c|c|c|c|c|c|c|}
\hline \multirow{4}{*}{ Food item } & & \multicolumn{6}{|c|}{ TIME (hrs) } \\
\hline & \multirow[b]{3}{*}{ Fish observed: } & \multirow{2}{*}{\multicolumn{2}{|c|}{$\begin{array}{c}0900 \\
2\end{array}$}} & \multirow{2}{*}{\multicolumn{2}{|c|}{$\begin{array}{c}2129 \\
8\end{array}$}} & \multirow{2}{*}{\multicolumn{2}{|c|}{$\begin{array}{c}0939 \\
8\end{array}$}} \\
\hline & & & & & & & \\
\hline & & Occurrence & $\%$ & Occurrence & $\%$ & Occurrence & $\%$ \\
\hline Harpacticoid & & 2 & 100 & 7 & 88 & 7 & 88 \\
\hline Calanoid & & 1 & 50 & 7 & 88 & 4 & 50.0 \\
\hline Siphonostomatida & & 0 & 0 & 0 & 0 & 2 & 25 \\
\hline Cyclopoid & & 0 & 0 & 0 & 0 & 1 & 12.5 \\
\hline Crustacean larvae & & 0 & 0 & 2 & 25.0 & 6 & 75.0 \\
\hline Polychaeta larvae & & 0 & 0 & 0 & 0 & 1 & 12.5 \\
\hline Mollusca & & 0 & 0 & 1 & 5.9 & 1 & 12.5 \\
\hline Mollusca & & 0 & 0 & 0 & 0 & 0 & 0 \\
\hline
\end{tabular}

\section{Discussion}

\subsection{Environmental Parameters and Plankton}

The daily fluctuation of salinity, temperature, dissolved oxygen and $\mathrm{pH}$ could possibly relate to the location of the sampling site which received direct freshwater run-off during low tide. The situation improved when seawater filled in the lagoon at night. Coastal zooplankton was commonly dominated by the calanoid copepods [15]. The changes in the zooplankton community structure of a small coastal lagoon might be the outcome of the fluctuation of freshwater and seawater inflow in the area which obviously affect the salinity condition [16 and 17]. The mangroves could be more important to the zooplankton than the seagrasses [18 and 19] in term of the diversity as shown by the present study. Nonetheless, it is undeniable that both vegetative ecosystems support the fish population and their prey at the same time. The zooplankton community could be consisted of the salinity tolerant species, or they could be from the transient species which will move and forage between the mangroves and seagrass $[20]$.

\subsection{Fishes Caught in Setiu Lagoon}

The number of fish species caught in the present study could be considered low if compared to the result from seagrasses in Merchang lagoon (22 species) and it was influenced by the timing of catch [21]. The number would also be influenced by the salinity. A previous study also confirmed the role of salinity on fish assemblage in Merbok estuary in the Strait of Malacca [22].

Gerres oyena, G. abbreviates and G. filamentosus could inhabit and use the lagoon as their feeding ground $\lceil 23,24$ and 25]. Leioqnatus species preferred the coastal mangroves with muddy sand bottom which seemed to be the perfect foraging area [26 and 27]. On the other hand, some species, such as $S$. canaliculatus preferred seagrass [28]. Liza subviridis, T. quadrilineatus and A. interupta also preferred the seagrass which could be due the abundance of their prey [29 and 30].

\subsection{Stomach Content}

Stomach content can be used in analyzing the number of preys found in a particular habitat. In a recent study [31], there were about 128 food items found from the stomach of small fishes in the study area. A 
study in the Gulf of Thailand which involved sillaginid fishes reported that the species preferred calanoid copepods, polychaetes and gammarids [32]. The shallow water condition in Setiu Lagoon could only permit bottom feeder fish to forage efficiently [2 and 3]. Harpacticoid was one of the common copepods found in fish stomach 「33ן.

The abundance of prey did not show any effect towards diet preferences. This was supported in earlier studies $\lceil 8$ and 9]. The high abundance of calanoid copepods in the zooplankton community in the lagoon did not influence the preference of diet in those small fishes. The result supported earlier findings [7], on the possible preference of the fishes towards the non-calanoid zooplankton diet. Nonetheless, longer sampling period at different part of the lagoon will be needed to confirm the results of the present study. There was a possibility that the fishes were grazing on the bottom sediment and consumed benthic harpacticoid copepods [34].

\section{Conclusion}

The small fish community of Setiu Lagoon was dominated by genus Gerres. It was obvious that the fishes caught during the 24hours sampling period were from the species associated with the coastal lagoon and estuarine habitat. The number could be higher at night particularly in the seagrass. They depended more on harpacticoid copepods and crustacean larvae as their main diet even though the abundance of calanoids and other holoplanktons were high. This indicated their grazing activity at the bottom sediment of the lagoon. Further investigation on the feeding behavior of these small fishes could explain the reason of high number of harpacticoids found in their stomach content.

Acknowledgement. The authors acknowledged the technical support from University Malaysia Terengganu and financial support from IIUM RIGS grant number RIGS 16-315-0479 awarded to the first author.

\section{References}

1. Soni, H. B. and S. Thomas, "Occurrence of zooplanktons at sacred palustrine habitat, Central Gujarat, India, with conservation and management strategies". International Journal of Environment, vol. 3, no.1, pp. 111-121, 2014.

2. Ikejima, K., P. Tongnunui, T. Medei and T. Taniuchi, "Juvenile and small fishes in a mangrove estuary in Trang province, Thailand: seasonal and habitat differences," in Estuarine, Coastal and Shelf Science. Elsevier, 2003, pp.447-457.

3. Souza, A.T., E. Dias, A. Nogueira, J. Campos, J.C. Marques and I. Martin, "Population ecology and habitat preferences of juvenile flounder Platichthys flesus (Actinopterygii: Pleuronectidae) in a temperate estuary", Journal of Sea Research, vol. 79, pp. 60-69, 2013.

4. Diaz, R.J., G.R. Cutter and K.W. Able, "The importance of physical and biogenic structure to juvenile fishes on the shallow inner continental shelf," in Estuaries. Springer, 2003, pp.12-20.

5. Scharf, F.S., J. P. Manderson and M.C. Fabriziob, "The effects of seafloor habitat complexity on survival of juvenile fishes: Species-specific interactions with structural refuge". Journal of Experimental Marine Biology and Ecology, vol. 335, pp. 167-176, 2006.

6. Shahidul Islam, M., M. Hibino and M. Tanaka, "Distribution and diets of larval and juvenile fishes: Influence of salinity gradient and turbidity maximum in a temperate estuary in upper Ariake Bay, Japan," in Estuarine, Coastal and Shelf Science. Elsevier, 2006.

7. Bernal, A., M.P. Olivar, F. Maynou and M.L.F. de Puelles, "Diet and feeding strategies of mesopelagic fishes in the western Mediterranean," in Progress in Oceanography. Elsevier, 2015.

8. Monteiro, D.P., T. Giarrizzo and V. Isaac, "Feeding ecology of juvenile dog snapper Lutjanus jocu (Bloch and Schneider, 1801) (Lutjanidae) in intertidal mangrove creeks in Curuçá estuary (Northern Brazil)", Brazilian Archives of Biology and Technology, vol. 52, no. 6, pp. 1421-1430, 2009.

9. Schabetsberger, R., C. A. Morgan, R. D. Brodeur, C. L. Potts, W. T. Peterson and R. L. Emmett, "Prey selectivity and diel feeding chronology of juvenile chinook (Oncorhynchus tshawytscha) and coho (O. kisutch) salmon in the Columbia River plume," Fisheries Oceanograph, vol.12, no.6, pp.:523-540, 2003. 
10. Baldo, F. \& P. Drake, "A multivariate approach to the feeding habits of small fishes in the Guadaquivir Estuary," Journal of Fish Biology, vol. 61, no. sA, pp. 21-32, 2002.

11. Tahir, N.M., H.M. Abd Rahim and M.K.A., Rashid, "Distribution and characterization of hydrocarbons in sediments of Setiu Wetland, Terengganu: A preliminary study," Malaysia Journal of Analytical Sciences, vol. 10, no. 1, pp. 177-184, 2006.

12. Suratman, S., A.N.A.R. Hussein, M.T. Latif and K. Weston, "Reassessment of physico-chemical water quality in Setiu Wetland, Malaysia," Sains Malaysiana, vol. 43, no. 8, pp.1127-1131, 2014.

13. Brehmer, P., T. Laugier, J. Kantoussan, F. Galgani and D. Mouillot, "Does coastal lagoon habitat quality affect fish growth rate and their recruitment? Insights from fishing and acoustic surveys," Estuarine, Coastal and Shelf Science, vol. 126, pp.1-6, 2013.

14. Emmanuel, B.E. and I.C. Onyema, "The Plankton and fishes of a tropical creek in South-Western Nigeria," Turkey Journal of Fisheries and Aquaculture Science, vol. 7, pp. 105-113, 2007.

15. Zaleha, K., I. Sulong, B.Y. Kamaruzaman and B.A.W. Mohd.Affendy, "Species composition and abundance of planktonic copepods in Pahang estuaries," Malaysia. Journal of Sustainability Science and Management, vol. 3, no. 1, pp. 11-22, 2008.

16. Hwang, J-S. R. Kumar, C-W. Hsieh, A. Y. Kuo, S. Souissi, M-H. Hsu, J.T. Wu, W-C.Liu, C-F., Wang and Q-C. Chen, "Patterns of zooplankton distribution along the marine, estuarine, and riverine portions of the Danshuei ecosystem in Northern Taiwan," Zoological Studies, vol. 49, no. 3, pp. 335-352, 2010.

17. Ara, R., A. Arshad, L. Musa, S. M. N. Amin, and P. Kuppan, "Feeding habits of larval fishes of the family Clupeidae (Actinopterygii: Clupeiformes) in the estuary of River Pendas, Johor, Malaysia," Journal of Fisheries and Aquatic Science, vol. 6, no. 7, pp. 816-821, 2011.

18. Jaxion-Harm, J., C. Pien, J.E. Saunders and M.R. Speight, "Distribution of fish, crustacea and zooplankton at different distances from mangrove prop roots within a semi-isolated lagoon," Journal of the Marine Biological Association of the United Kingdom, vol. 93, no.6, pp. 1471-1479, 2013.

19. Abu El-Regal, M.A. and N.K. Ibrahim, " Role of mangroves as a nursery ground for juvenile reef fishes in the southern Egyptian Red Sea," Egyptian Journal of Aquatic Research, vol. 40, no. 1, pp.71-78, 2014.

20. Vaslet, A., D.L. Philips, C. France, I.C. Feller, and C.C. Baldwin, "The relative importance of mangroves and seagrass beds as feeding areas for resident and transient fishes among different mangrove habitats in Florida and Belize: Evidence from dietary and stable-isotope analyses," Journal of Experimental Marine Biology and Ecology, vol. 434-435, pp. 81-93, 2012.

21. Aziz, A., J.S.Bujang, M.H. Zakaria, Y. Suryana and M.A. Ghaffar, "Fish communities from seagrass bed of Merchang Lagoon, Terengganu, Peninsular Malaysia," Coastal Marine Science, vol. 30, no.1, pp. 268-275, 2006.

22. Mansor, M.I., M.Z Mohammad-Zafrizal, M.A.Nur-Fadhilah, Y. Khairun, and W.O. Wan-Maznah, "Temporal and spatial variations in fish assemblage structures in relation to the physico-chemical parameters of the Merbok Estuary, Kedah," Journal of Natural Sciences Research, vol. 2, no. 7, pp.110-127, 2012.

23. Woodland, D.J., "Gerreidae. In: FAO species identification sheets for fishery purpose Western Indian Ocean fishing area 51.Vol. 2. (eds. W. Fischer and G. Bianchi)," FAO, Rome, 1984.

24. Iwatsuki, Y., S. Kimura and T. Yoshino, "Redescriptions of Gerres baconensis (Evermann\& Seale, 1907), G. equulus Temminck, Schlegel, 1844 and G. oyena (Forsskål, 1775), included in the "G. oyena complex", with notes on other related species (Perciformes: Gerreidae)," Ichthyology Research, vol. 46, no. 4, pp. 377-395, 1999.

25. The IUCN red list of threatened species, Available: http://www.iucnredlist.org

26. Kühlmorgen-Hille, G., "Leiognathidae.In: FAO species identification sheets for fishery purposes. Eastern Indian Ocean (fishing area 57) and Western Central Pacific (fishing area 71) vol. 2 (eds. W. Fischer and P.J.P. Whitehead)," FAO, Rome, 1974.

27. James, P.S.B.R., "Leiognathidae. In: FAO species identification sheets for fishery purposes. Western Indian Ocean (Fishing Area 51) vol. 2 (eds. W. Fischer and G. Bianchi)," FAO, Rome, 1984.

28. Unsworth, R.K.F., S.L. Hinder, O.G. Bodger and L.E. Cullen-Unsworth, "Food supply depends on seagrass meadows in the coral triangle," Environmental Research Letters, vol. 9, no. 9, pp. 1-9, 2014.

29. Rahman, A.K.A., Freshwater Fishes of Bangladesh, first edition. Zoological Society of Bangladesh, University of Dhaka, Dhaka, Bangladesh, 2005.

30. Four line Striped Grunter, Pelate squadrilineatus, in Fishes of Australia, Available: http://www.fishesofaustralia.net.au/home/species/69. 
31. Ferrareza, M., M.G. Nogueira and L. Casatti, "Differences in ichthyofauna feeding habits among lateral lagoons and the river channel in a large reservoir," Brazilian Journal of Biology, vol. 75, no. 2, pp. 380-390, 2015.

32. Hajisamae, S., P.Yeesin and S. Ibrahim, "Feeding ecology of two sillagilid fishes and trophic interrelations with other co-existing species in the southern part of South China Sea," Environmental Biology of Fishes, vol.76, pp. 167-176, 2006.

33. Ingólfsson, A. and B. K. Kristjánsson, "Diet of juvenile lumpsucker Cyclopterus lumpus (Cyclopteridae) in floating seaweed: effects of ontogeny and prey availability," Copeia, vol. 2002, no. 2, pp. 472-476, 2002.

34. Schu"ckel, S., A.F. Sell, T.C. Kihara, A. Koeppen, I. Kro"ncke and H.R. Helgol, "Meiofauna as food source for small-sized demersal fish in the southern North Sea," Marine Research, vol. 67, no. 2, pp.203-218, 2013. 